TAO, Vol.6, No.2, 285-298, June 1995

\title{
Site Effect Analysis From the Records of the Wuku Downhole Array
}

\author{
KUO-LIANG WEN ${ }^{1}$, LI-YUAN FEI $^{2}$, HAN-YIH PENG ${ }^{3}$ and CHUN-CHIH LIU ${ }^{1}$
}

(Manuscript received 27 December 1994, in final form 15 March 1995)

\begin{abstract}
The first downhole array in the Taipei Basin was installed in the Sewage Disposal Plant of the Wuku Industrial Area at the end of 1993. It is a subproject of "An Integrated Survey of the Subsurface Geology and Engineering Environment of the Taipei Basin" which has been conducted since 1991 by the Central Geological Survey, Ministry of Economic Affairs. The main purpose of this downhole array project has been to study the basin effects on seismic waves. By the end of November 1994, 16 earthquakes were recorded by this downhole array. Although only weak motions were recorded, some analysis can already be done. Through the travel time analysis of seismic waves, the results of $V_{p}$ and $V_{s}$ for the soil layer from surface to the depth of 352 meters is calculated. On the basis of a comparison of the peak ground motions at different depths with that at ground surface, it is determined that the main amplification exists in the top 60 meters of the soft soil layer. No nonlinear amplification effect occurs in this weak motion data set. The equation representing the variation of horizontal peak ground acceleration with respect to depth is obtained by using regression analysis. Finally, the ground responses are analyzed in the frequency domain. The spectral ratios between station pairs of different depths show variations of amplitude at different frequencies, and they verify the average velocity between each station pair.
\end{abstract}

(Key words: Downhole array, Basin effects, $\mathrm{V}_{p}$ and $\mathrm{V}_{s}$, Spectral ratios)

\section{INTRODUCTION}

A research project has been conducted by the Central Geological Survey, Ministry of Economic Affairs, since July 1991, for the purposes of engineering construction, underground

\footnotetext{
1 Institute of Earth Sciences, Academia Sinica, P. O. Box 1-55, Nankang, Taipei, Taiwan, R.O.C.

2 Central Geological Survey, Ministry of Economic Affairs, Taiwan, R.O.C.

3 Institute of Geophysics, National Central University, Chungli, Taiwan, R.O.C.
} 
water management, ground subsidence prediction, the study of the basin effects of seismic waves, and geological sciences. This five-year plan called "The Integrated Survey of Subsurface Geology and Engineering Environment of the Taipei Basin". Among the plan, the Institute of Earth Sciences, Academia Sinica was entrusted with the study of the basin effects on seismic waves. This project proposed the installation of downhole arrays in the Taipei Basin to analyze the variation of seismic waves propagated from basement to ground surface.

Many studies (e.g., Gutenberg, 1957; Hudson, 1972; Vidale and Helmberger, 1988; Kawase and Aki, 1989; Wen et al., 1992; Wen and Yeh, 1992; Wang and Chuen, 1992; Wang and Chen, 1993) have found that seismic waves passing through the soft soil layer of an alluvium basin have an amplification effect. For example, the Mexico earthquake of September 19, 1985, caused considerable damage in Mexico City, about $400 \mathrm{~km}$ away from the epicenter. This is because the city is located on top of a very soft soil layer (Çelebi $e t$ al., 1987). In like manner, Taipei City is on top of an alluvium basin, and many buildings experienced damage or even collapsed in the Taipei Basin during the Hualien earthquakes of May 20 and November 15, 1986. Those epicenters were $100 \mathrm{~km}$ away from the Taipei Basin (Tsai et al., 1986; Tsai, 1988). One study, using the ray method (Yeh et al., 1988), found a focusing effect in the Taipei Basin as the earthquake occurred in the Hualien area. In the same way, the alluvium basin of the Lanyang Plain also showed amplification effects (Wen et al., 1992; Wen and Yeh, 1992; Wang and Chuen, 1992; Wang and Chen, 1993). Observed records from a downhole array can provide direct and efficient data for the study of soil amplification.

Another important research topic concerns nonlinear soil amplification as an influence of a soft soil layer on seismic waves. It can be seen in many studies (Chin and Aki, 1991; Beresnev et al., 1995a, b; Wen et al., 1993, 1994, 1995; Wen, 1994) that the same soft soil layer shows different amplification effects for strong and weak input motions. For the basis of correction, how, then, is it possible to determine this nonlinear relationship in strong ground motion prediction? In fact, the strong motion data of the downhole seismic array is most useful to determine this nonlinear relationship.

\section{WUKU DOWNHOLE ARRAY AND RECORDS}

Five seismometers are installed in the Wuku observation site. It is located at the western part of the Taipei Basin. The black triangle in Figure 1 represents the site position. This array includes one free-surface accelerometer and four downhole sensors. The depths of the four holes are $30 \mathrm{~m}, 60 \mathrm{~m}, 141 \mathrm{~m}$ and $352 \mathrm{~m}$, respectively. These five seismographs connect to a PC-based central recording system. The site configuration is shown in Figure 2. The downhole array observation system includes accelerometers, a digital recording system and a trigger. The characteristics of the whole system are as follows:

\subsection{Accelerometer}

Both products of Kinemetrics Inc., the FBA23 and the FBA23DH are used for the surface station and for downhole sites, respectively. With the full scale of $\pm 1 \mathrm{~g}$, the natural frequency is $50 \mathrm{~Hz}$, and the damping ratio is 0.65 .

\subsection{Recording System}

A PC-based digital recording system was designed by the Institute of Earth Sciences, Academia Sinica (Liu et al., 1993). Totally 32 channels are used in this system. The first 


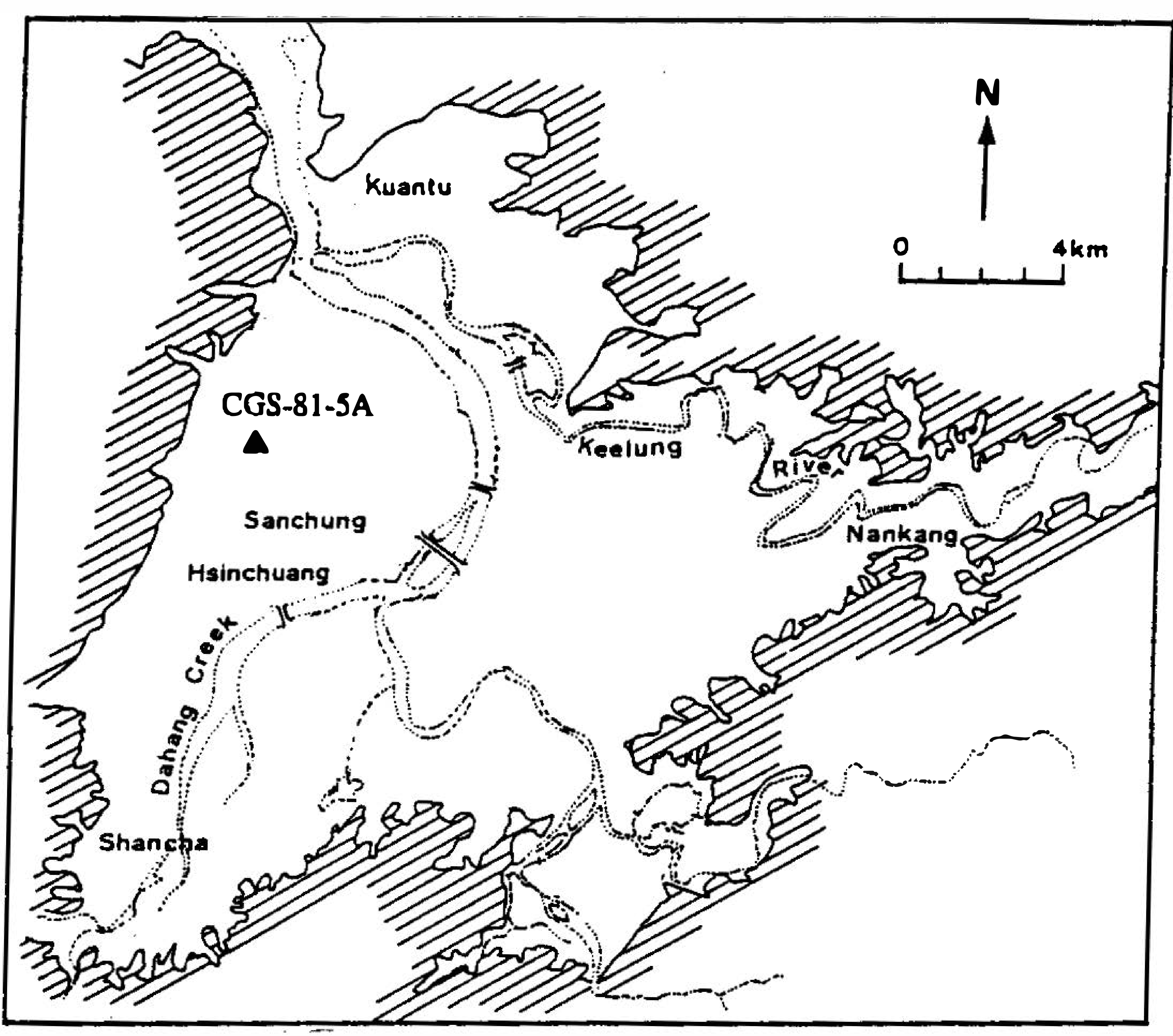

Fig. 1. Map showing the location of the Wuku downhole site (black triangle) in the Taipei Basin.

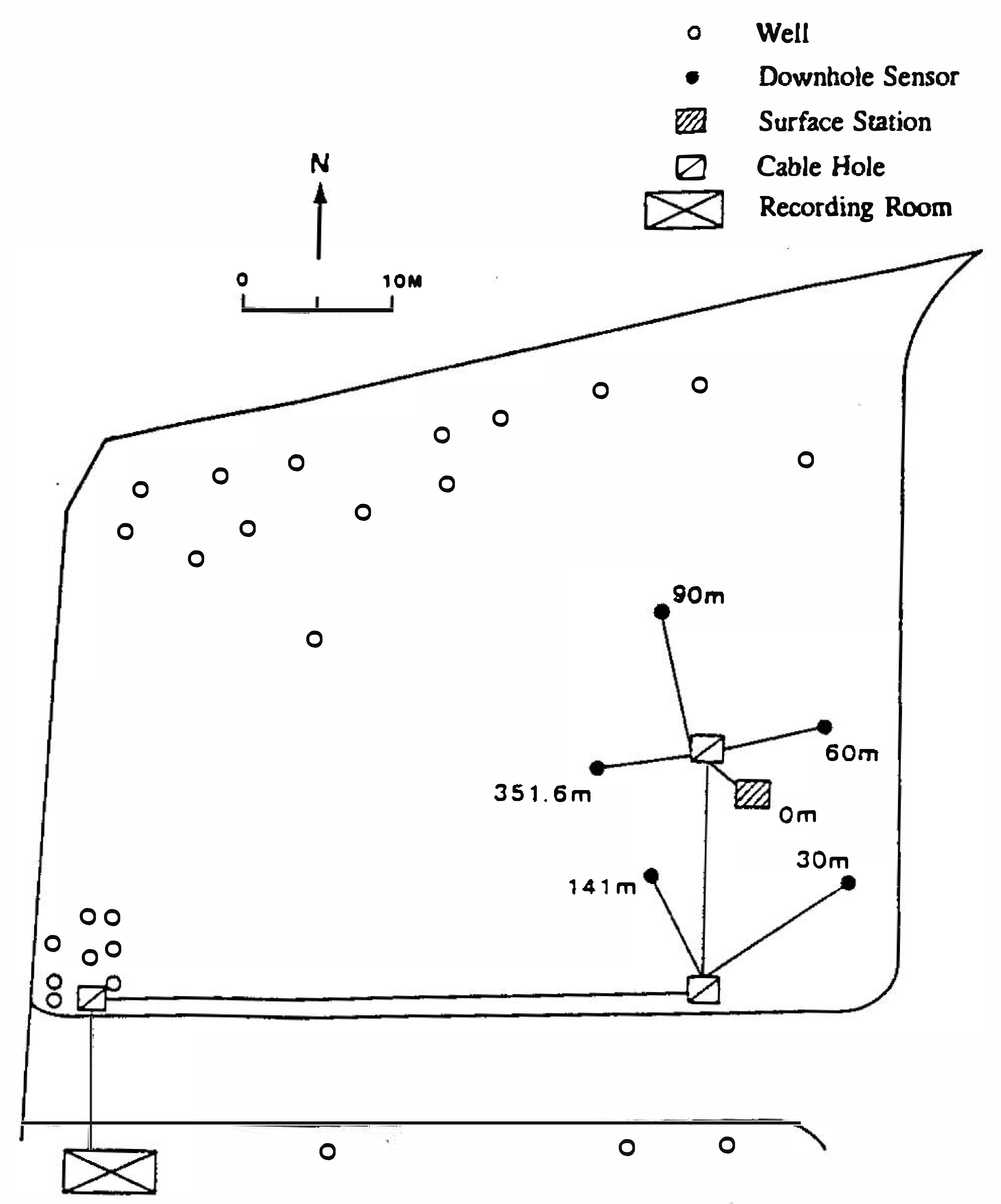

Fig. 2. Site configuration of the Wuku downhole site. 
16 channels (including 5 stations, each with three components and one channel of GPS time signal) use gains equal to 1 to record the ground motion, while the other 16 channels amplify 10 times before recording. The pre-event memory is $15 \mathrm{sec}$, recording time is set at at least $45 \mathrm{sec}$, and the sampling rate is $200 \mathrm{pts} / \mathrm{sec}$. A high resolution 16-bit A/D converter is used. Accordingly, this system can have at least a 90-dB dynamic range and a 16-bit resolution. System softwares are referred to the public software of the IASPEI, and the SUDS format is used for the data. Nevertheless, many public domain softwares can be used to process the data recorded by this system.

\subsection{Trigger}

The trigger criterion of this system is set at a fixed level. If there are five channels larger than this level, then it is defined as an event and begins to store the data. At the test stage, the trigger level is set at about $0.3 \mathrm{gal}$, and the trigger level is adjustable.

Two months after the installation of the instruments, the seismometer at the $352 \mathrm{~m}$ depth was malfunctioning. Before it was fixed, another sensor was temporarily put in a hole $90 \mathrm{~m}$ in depth. The $352 \mathrm{~m}$ depth sensor was fixed and re-installed in the last half of the month of November 1994. Then, the 90-meter depth instrument was pulled out for other use. Since the installation of the Wuku downhole array, 16 earthquakes were recorded by this downhole array up to the end of November 1994. Their magnitudes range from 3.4 to 6.4 . All parameters are listed in Table 1, and the epicenter distribution is plotted in Figure 3. Most earthquakes were far away from the downhole array, causing the peak ground accelerations recorded at ground surface to be lower than 25 gals in each of these 16 events.

\section{CORRECTION OF THE INSTRUMENT ORIENTATION}

Originally, each sensor contained a compass device which is a microprocessor-controlled fluxgate compass subsystem to determine the azimuth during installation. The casing of the 90-meter depth hole is an iron casing, so the orientation at the installation time could not be measured. Using seismic data, the instrument orientation can be calculated by a statistical method.

The problem of downhole instrument orientation is solved by using the maximum crosscorrelation method (Yamazaki et al., 1992; Peng and Wen, 1993). At the Wuku downhole array, the orientation of the 60-meter depth instrument is known and can be used as the reference. The direction of the 90 -meter depth downhole instrument can be estimated by finding the maximum cross-correlation coefficient between the records of the reference and unknown sites. The records of the unknown station are rotated counterclockwise from $0^{\circ}$ to $180^{\circ}$ and $0^{\circ}$ to $-180^{\circ}$ with a $1^{\circ}$ interval, and the cross-correlation coefficient is calculated from the records of the referent site at each angle. The results are shown in Figure 4. The average result from all events shows that the longitudinal direction of the downhole instrument at depths of $90 \mathrm{~m}$ is $\mathrm{N} 97.7^{\circ} \pm 1.3^{\circ} \mathrm{W}$, which is corrected from the orientation of the 60 -meter depth instrument of $\mathrm{N} 2.3^{\circ} \mathrm{E}$. Figure 5 shows the corrected waveform of the EW component of the June 5, 1994, Nanau earthquake.

\section{VELOCITY STRUCTURE ANALYSIS}

To study the soil layer response, it is necessary to know the velocity structure first. The velocities of the Songshan and Chingmei Formations are the most important for engineers in 
Table 1. Earthquake parameters recorded by the Wuku downhole array.

\begin{tabular}{|c|c|c|c|c|c|c|c|}
\hline \multirow[t]{2}{*}{$\begin{array}{l}\text { EVENT } \\
\text { NO. }\end{array}$} & \multirow{2}{*}{$\begin{array}{c}\text { ORIGDN } \\
\text { TIME } \\
\text { (UT) }\end{array}$} & \multirow[t]{2}{*}{ EPICENTER } & \multirow[t]{2}{*}{$\begin{array}{l}\text { DEPTH } \\
(\mathrm{km})\end{array}$} & \multirow[t]{2}{*}{$\mathbf{M}_{\mathrm{L}}$} & \multicolumn{3}{|c|}{$\mathrm{PGA}^{*}(\mathrm{gal})$} \\
\hline & & & & & V & EW & NS \\
\hline 1 & $\begin{array}{l}1994-02-04 \\
21: 11: 38.46\end{array}$ & $\begin{array}{l}121^{\circ} 55.6^{\prime} \mathrm{E} \\
24^{\circ} 52.8^{\prime} \mathrm{N}\end{array}$ & 119 & 4.6 & 1.43 & 1.42 & 1.24 \\
\hline 2 & $\begin{array}{l}1994-03-06 \\
19: 37: 21.4\end{array}$ & $\begin{array}{l}122^{\circ} 00.0^{\prime} \mathrm{E} \\
24^{\circ} 49.2^{\prime} \mathrm{N}\end{array}$ & 94 & 5.4 & 2.64 & 5.45 & 7.46 \\
\hline 3 & $\begin{array}{l}1994-04-19 \\
23: 56: 17.50\end{array}$ & $\begin{array}{l}121^{\circ} 34.2^{\prime} \mathrm{E} \\
25^{\circ} 08.4^{\prime} \mathrm{N}\end{array}$ & 7 & 3.4 & 0.97 & 2.31 & 2.69 \\
\hline 4 & $\begin{array}{c}1994-04-30 \\
09: 14: 17.12\end{array}$ & $\begin{array}{l}122^{\circ} 04.4^{\prime} \mathrm{E} \\
24^{\circ} 21.2^{\prime} \mathrm{N}\end{array}$ & 4 & 5.0 & 1.39 & 2.70 & 1.95 \\
\hline 5 & $\begin{array}{c}1994-05-19 \\
06: 03: 40.99\end{array}$ & $\begin{array}{c}121^{\circ} 42^{\prime} .9^{\prime} \mathrm{E} \\
24^{\circ} 43.0^{\prime} \mathrm{N}\end{array}$ & 87 & 4.6 & 1.46 & 3.18 & 3.20 \\
\hline 6 & $\begin{array}{c}1994-05-23 \\
05: 36: 01.90\end{array}$ & $\begin{array}{l}122^{\circ} 41.4^{\prime} \mathrm{E} \\
23^{\circ} 55.2^{\prime} \mathrm{N}\end{array}$ & 7 & 5.8 & 1.50 & 2.40 & 2.99 \\
\hline 7 & $\begin{array}{c}1994-05-23 \\
06: 24: 51.90\end{array}$ & $\begin{array}{c}122^{\circ} 40.2^{\prime} \mathrm{E} \\
23^{\circ} 50.4^{\prime} \mathrm{N}\end{array}$ & 16 & 5.7 & 1.38 & 2.53 & 3.31 \\
\hline 8 & $\begin{array}{c}1994-05-23 \\
15: 16: 58.80\end{array}$ & $\begin{array}{l}122^{\circ} 38.4^{\prime} \mathrm{E} \\
23^{\circ} 51.6^{\prime} \mathrm{N}\end{array}$ & 6 & 5.8 & 4.35 & 8.66 & 6.53 \\
\hline 9 & $\begin{array}{c}1994-05-24 \\
04: 00: 40.40\end{array}$ & $\begin{array}{l}122^{\circ} 36.6^{\prime} \mathrm{E} \\
23^{\circ} 49.2^{\prime} \mathrm{N}\end{array}$ & 3 & 6.2 & 6.13 & 11.7 & 10.7 \\
\hline 10 & $\begin{array}{c}1994-05-24 \\
05: 48: 09.40\end{array}$ & $\begin{array}{l}122^{\circ} 39.0^{\prime} \mathrm{E} \\
23^{\circ} 45.6^{\prime} \mathrm{N}\end{array}$ & 7 & 5.7 & 1.03 & 1.60 & 1.98 \\
\hline 11 & $\begin{array}{c}1994-06-05 \\
01: 09: 30.10\end{array}$ & $\begin{array}{l}121^{0} 50.4^{\prime} \mathrm{E} \\
24^{\circ} 27.6^{\prime} \mathrm{N}\end{array}$ & 5 & 6.2 & 11.21 & 19.80 & 24.70 \\
\hline 12 & $\begin{array}{c}1994-06-05 \\
05: 51: 43.00\end{array}$ & $\begin{array}{l}121^{\circ} 54.6^{\prime} \mathrm{E} \\
24^{\circ} 27.6^{\prime} \mathrm{N}\end{array}$ & 5 & 4.8 & 1.23 & 1.97 & 1.95 \\
\hline 13 & $\begin{array}{c}1994-09-16 \\
06: 20: 20.60\end{array}$ & $\begin{array}{l}118^{\circ} 43.2^{\prime} \mathrm{E} \\
22^{\circ} 29.4^{\prime} \mathrm{N}\end{array}$ & 45 & 6.4 & 3.21 & 6.35 & 6.13 \\
\hline 14 & $\begin{array}{c}1994-10-05 \\
01: 13: 24.80\end{array}$ & $\begin{array}{l}121^{\circ} 41.4^{\prime} \mathrm{E} \\
23^{\circ} 10.2^{\prime} \mathrm{N}\end{array}$ & 29 & 5.8 & 5.97 & 12.17 & 11.24 \\
\hline 15 & $\begin{array}{l}\text { 1994-10-12 } \\
09: 08: 21.40\end{array}$ & $\begin{array}{l}122^{\circ} 03.6^{\prime} \mathrm{E} \\
24^{\circ} 50.4^{\prime} \mathrm{N}\end{array}$ & 78 & 5.7 & 3.16 & 6.11 & 6.39 \\
\hline 16 & $\begin{array}{c}1994-11-26 \\
11: 17: 35.30 \\
\end{array}$ & $\begin{array}{l}122^{\circ} 13.8^{\prime} \mathrm{E} \\
24^{\circ} 40.8^{\prime} \mathrm{N} \\
\end{array}$ & 8 & 5.5 & 1.25 & 3.52 & 2.40 \\
\hline
\end{tabular}

*: PGA recorded at free surface. 


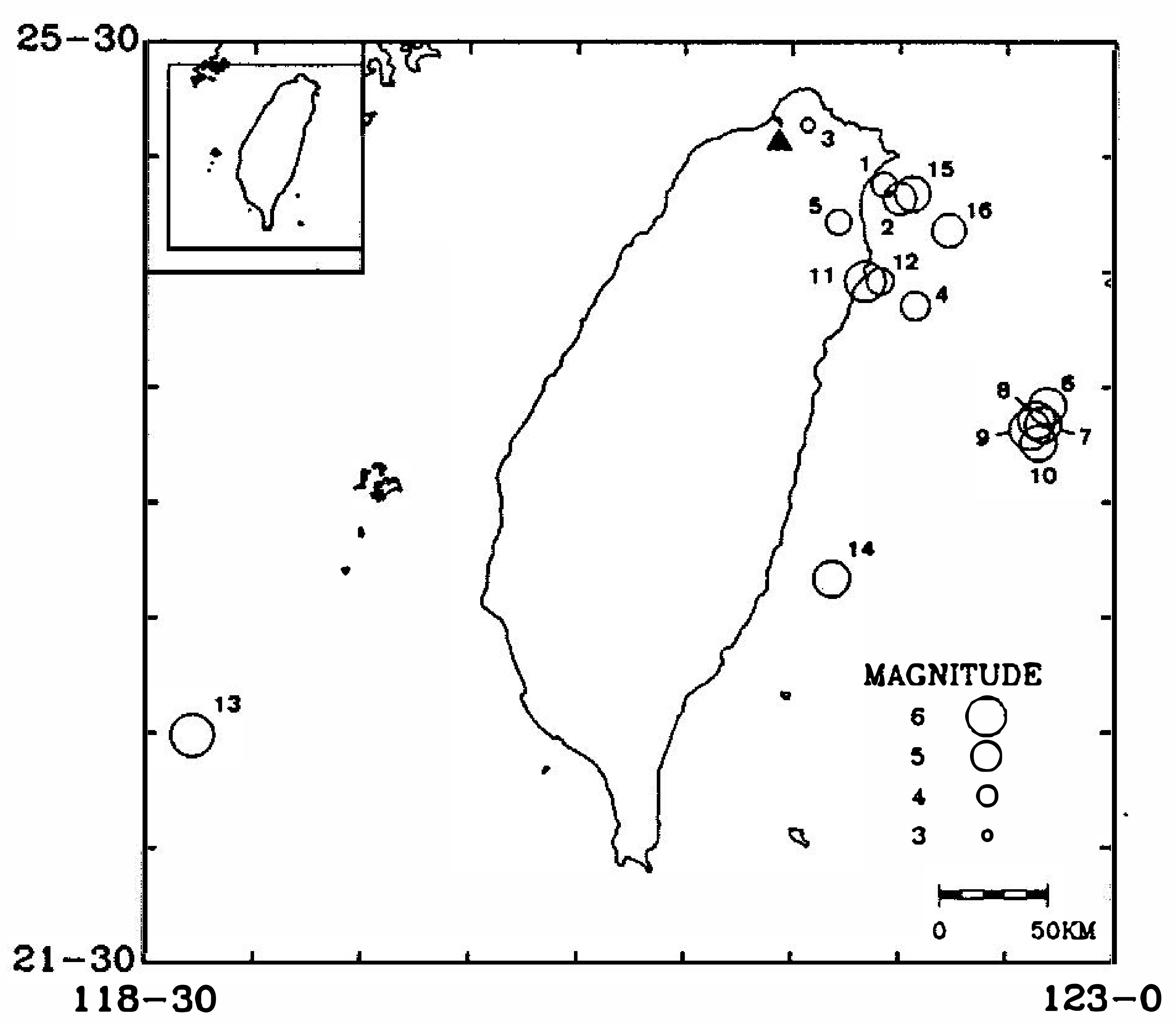

Fig. 3. Epicenter distribution recorded by the Wuku downhole array. The solid triangle represents the Wuku downhole site.

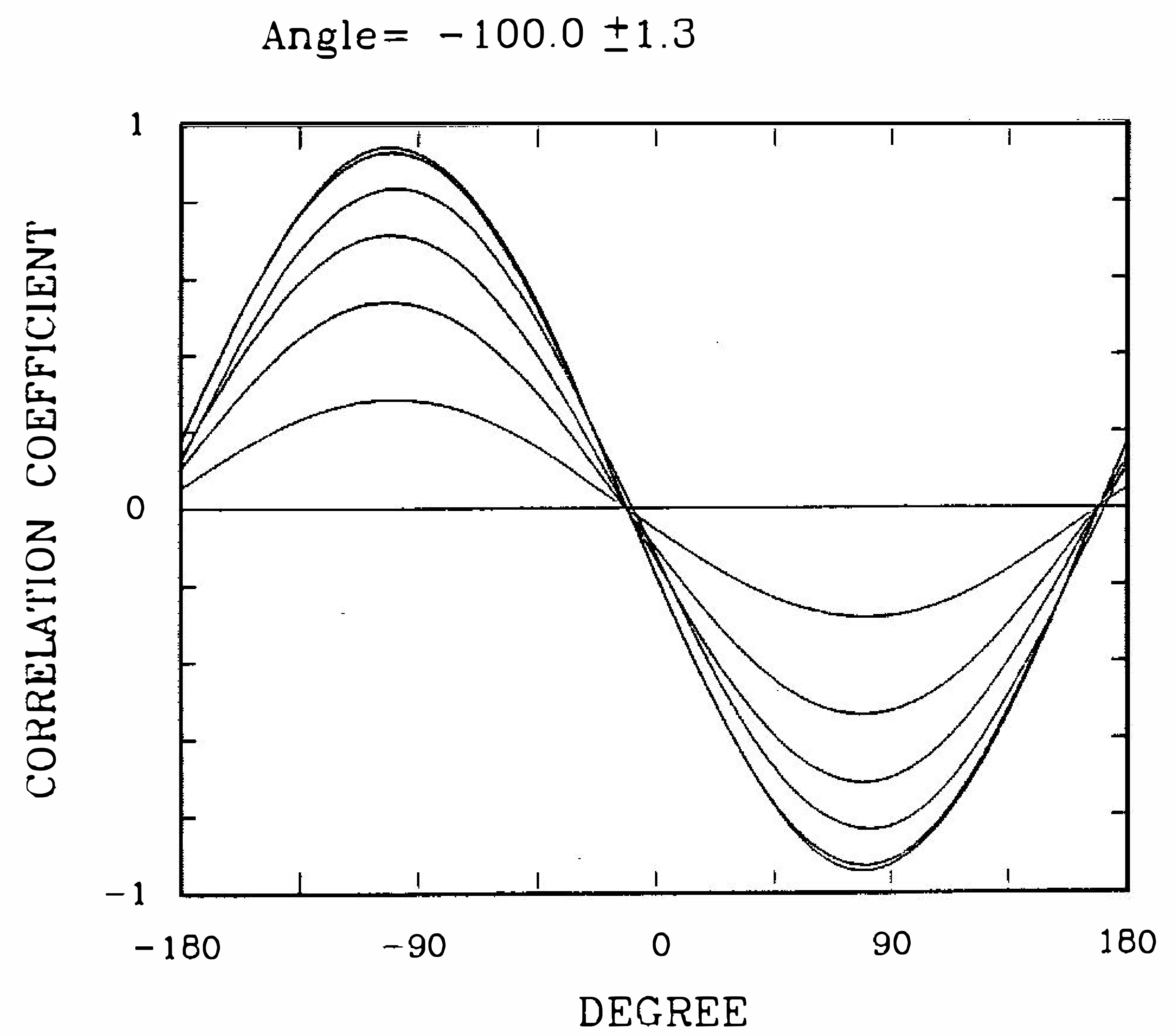

Fig. 4. Cross-correlation coefficients between $60-$ and $90-\mathrm{m}$ depth station pairs.

the Taipei area. The P-wave velocity structure can be seen from previous seismic refraction and reflection studies (Table 2, Fong et al., 1976; Wang et al., 1994). The S-wave velocity is only known in shallow layers of the Songshan Formation. For example, Lin (1994) used the well-logging method and got the shallow P-and S-wave velocity profiles presented in Figure 6. Lin et al. (1980) measured 10 observation points in the central area of the Taipei Basin. By downhole measurement, they obtained a shear wave velocity of the Songshan Formation lower than $370 \mathrm{~m} / \mathrm{sec}$. 


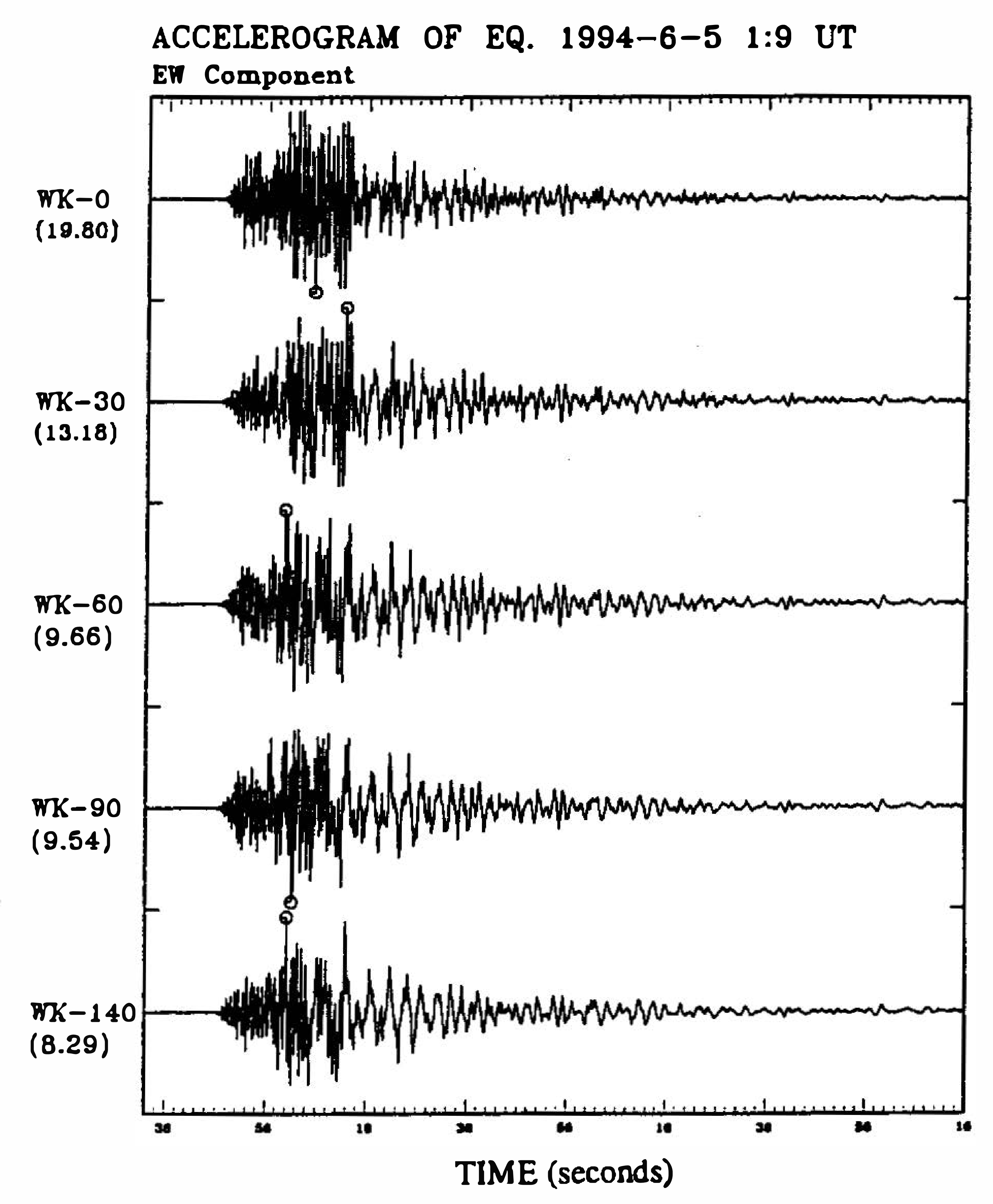

Fig. 5. Corrected waveform of the EW component of the June 5, 1994, Nanau earthquake.

Table 2. P-wave velocity structure of the Taipei Basin (Wang et al., 1994).

\begin{tabular}{|c|c|c|c|}
\hline $\begin{array}{l}\text { Depth } \\
\text { (m) }\end{array}$ & $\begin{array}{r}\text { Velocity } \\
(\mathrm{m} / \mathrm{sec})\end{array}$ & $\begin{array}{l}\text { Velocity* } \\
\text { (m/sec) }\end{array}$ & Layer \\
\hline $0-10$ & 400 & 350 & Soil \\
\hline $10-60$ & 1550 & 1500 & Songshan F. \\
\hline $60-120$ & 2050 & 1260 & Chingmei F. \\
\hline $120-180$ & 2400 & 2410 & U. Hsinchuan F. \\
\hline $180-240$ & 3100 & & L. Hsinchuan F. \\
\hline$>240$ & 3800 & 3640 & Nankang F. \\
\hline
\end{tabular}

*: Fong et al. (1976).

The shear wave velocity structure under the Taipei Basin is, therefore, still not very clearly defined. From the data recorded by this downhole array, the arrival times of the Pand S-waves at each station can be picked out. Based on the distance between two stations and the difference in travel times, the average velocity within this two-station pair can be calculated. The results are listed in Table 3. Figure 7 presents the $\mathrm{P}$ - and $\mathrm{S}$-wave velocity profiles obtained at the Wuku downhole array. These are the results from many events; thus, a mean value and one standard deviation area may be determined. Although ray tracing back 


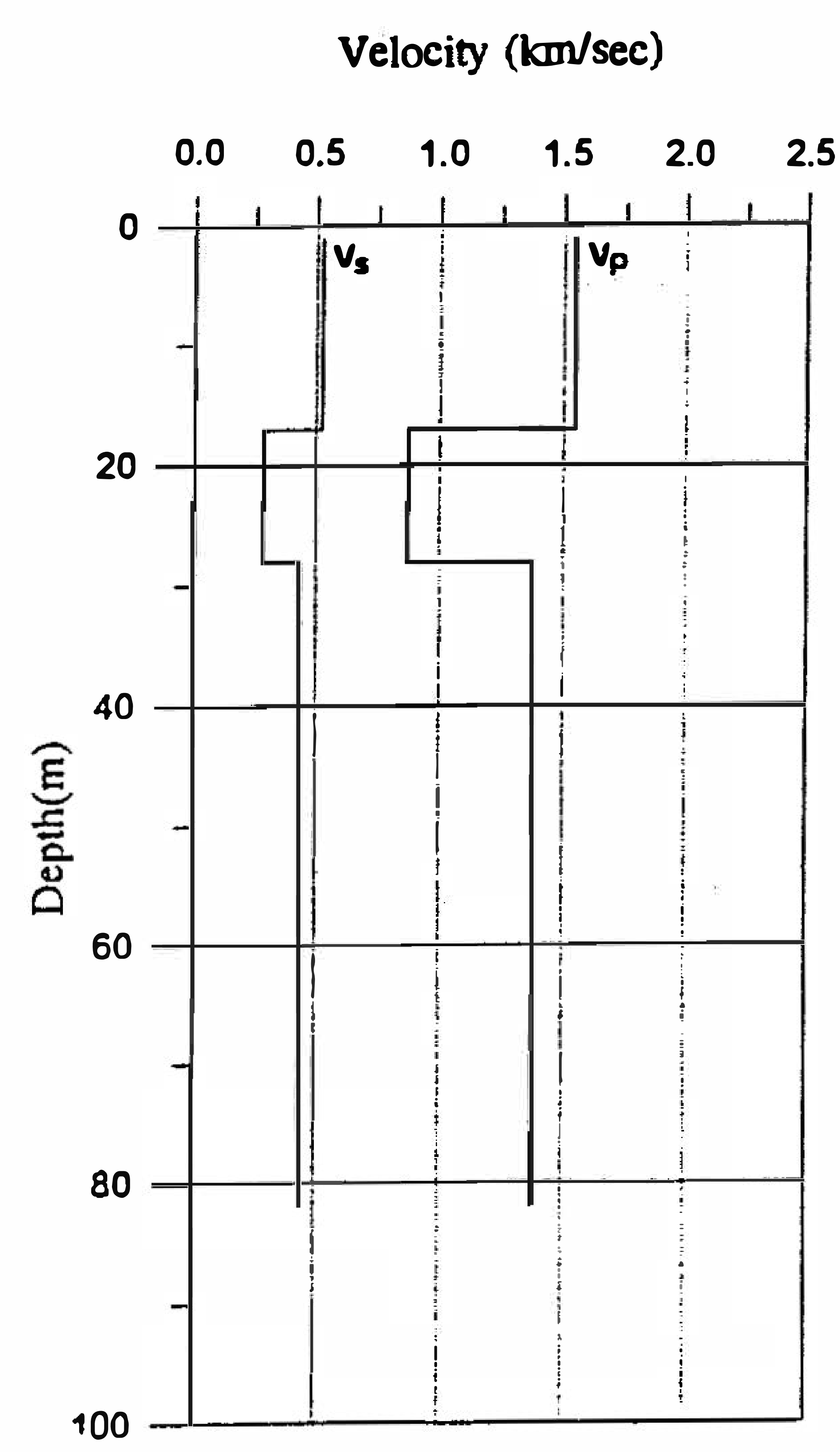

Fig. 6. Velocity profile from the cross-hole survey (Lin, 1994).

to the hypocenter for each earthquake may produce improved individual estimates of the velocity, unknown variations in source and path are probably of equal consequence. Because the 16 events differ, the averaging procedure is expected to reduce the resulting error for the mean values to a significant extent. From $141 \mathrm{~m}$ to $352 \mathrm{~m}$, only one value is obtained because only one event was recorded after the sensor was reinstalled at the depth of $352 \mathrm{~m}$.

\section{SOIL LAYER RESPONSE ANALYSIS AT DIFFERENT DEPTH}

Most engineers judge the ground motion level by the horizontal peak ground acceleration (PGA). The variation of the PGA with respect to depth can be analyzed through the records of the downhole array. Figure 8 compares the PGA at different depths. The dashed line here shows a slope in unity. Data points falling on this line mean that the ground motions at these two stations are the same. It shows the seismic wave propagated from the lower depth layer to the upper layer has no amplification effect. It can be seen from Figures $8 \mathrm{c}$ and $8 \mathrm{~d}$ that the PGA has only a slight amplification for the ground motion from a depth of $141 \mathrm{~m}$ to a depth of $60 \mathrm{~m}$. The amplification effect, however, is significant in the top 60-meter soil layer (Figures $8 \mathrm{a}$ and $8 \mathrm{~b}$ ). The maximum PGA at ground surface is only about 25 gals. Figure 8 also shows this weak ground motion has only a linear amplification effect. A nonlinear amplification effect does not exist in this data set.

Because the deepest hole is not drilled to the basement, the station at free surface is used as a reference point to study the variation of the PGA with respect to depth. Figure 9 represents the distribution of the PGA at different depths, which normalizes to the PGA at ground surface. The shaded band represents \pm 1 standard deviation around the average 
Table 3. Average layer velocity in the Wuku area.

\begin{tabular}{ccccc}
\hline Depth $(\mathrm{m})$ & \multicolumn{2}{c}{$\mathrm{V}_{\mathrm{p}}(\mathrm{m} / \mathrm{sec})$} & \multicolumn{2}{c}{$\mathrm{V}_{\mathrm{s}}(\mathrm{m} / \mathrm{sec})$} \\
\hline & MEAN & S.D. & MEAN & S.D. \\
\hline $0-30$ & 1590 & 260 & 200 & 40 \\
$30-60$ & 1240 & 240 & 280 & 20 \\
$60-90$ & 1870 & 230 & 660 & 80 \\
$90-141$ & 2080 & 320 & 400 & 40 \\
$141-352$ & 1830 & - & 590 & - \\
\hline
\end{tabular}

(circles in Figure 9). As only one event was recorded by the sensor at the depth of 352 meters after being reinstalled, there is no shaded band from 141 to 352 meters. Figure 9 clearly shows that the PGA is reduced from surface to underground (inversely, it is amplified from underground to ground surface). At a depth lower than 60 meters, the ground motion level is less than one-half of that at ground surface. Using linear regression analysis, the attenuation curve of the normalized PGA with respect to depth is:

$$
\mathrm{NPGA}=\exp \left(-0.1195 \mathrm{D}^{0.4203}\right),
$$

where $D$ is the depth in meters. The curve is shown in Figure 9 by a solid curve.

Wen and Yeh (1992) compared the PGA with respect to depth at the Lotung downhole array. The results show that the PGA decreases very quickly with respect to depth in the upper 10 meters of the soil layer. The PGA at ground surface is roughly twice as great as those at depths greater than 20 meters. The result of the Wuku downhole array in the Taipei Basin does not decrease so fast. This is also consistent with the difference in the velocity structures in these two areas. The shear wave velocity in Lotung at near surface is lower than that in Wuku, so the decrease in the PGA in Lotung is faster than that in Wuku.

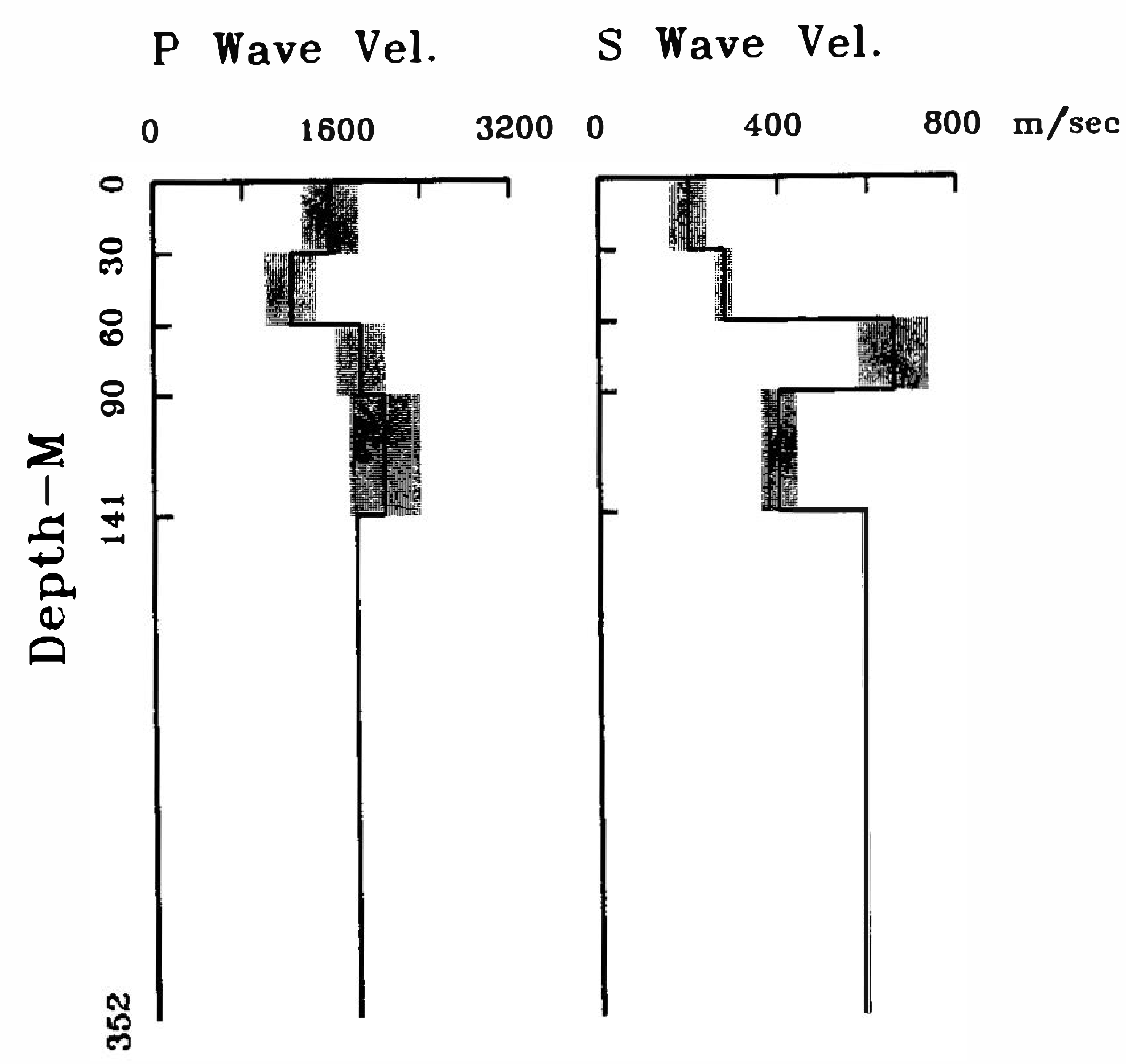

Fig. 7. Vp and Vs profiles calculated from the travel time analysis. The shaded areas represent \pm 1 standard deviation of the average. 

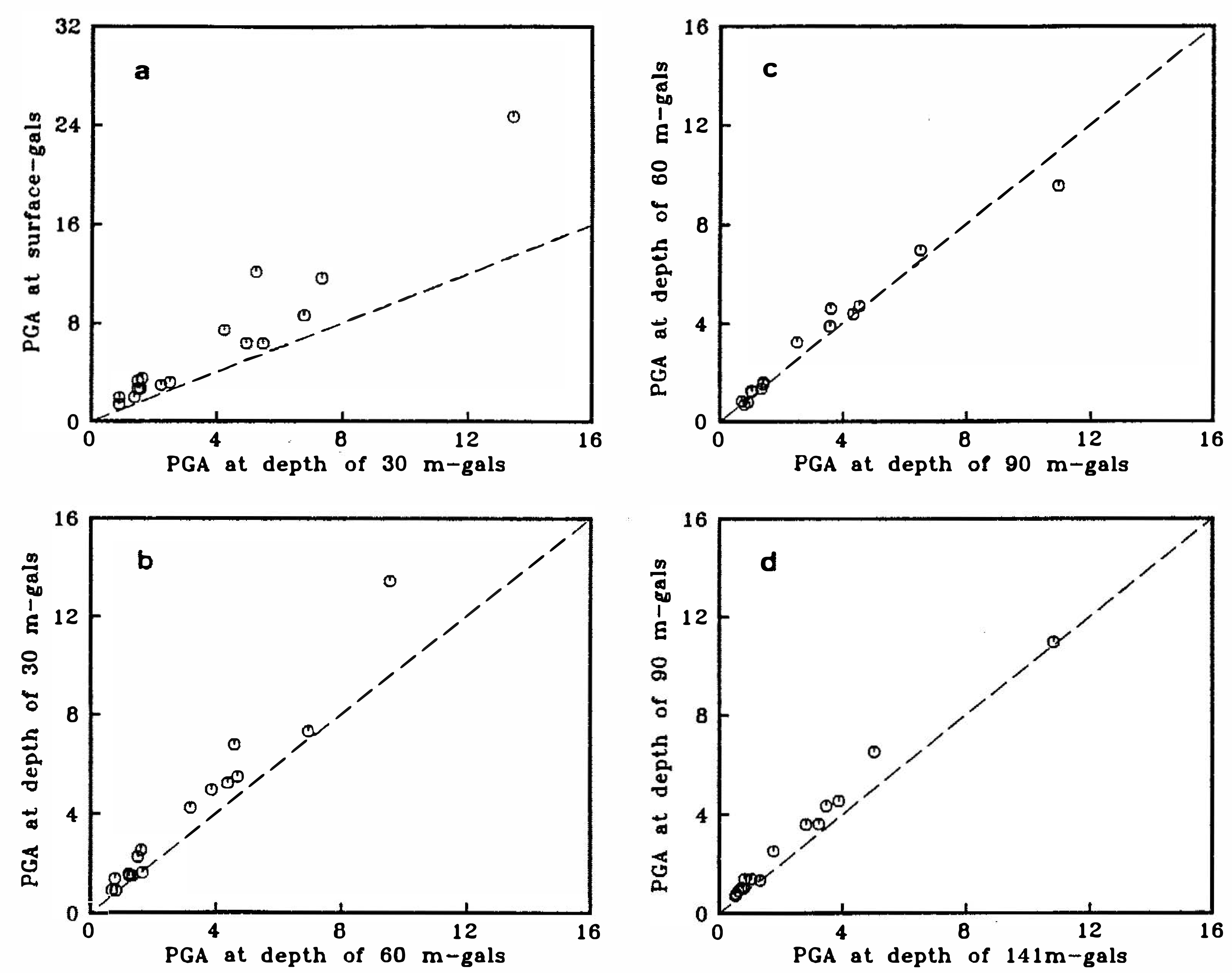

Fig. 8. PGA relationships of different depth pairs, (a) ground surface and $30 \mathrm{~m}$, (b) $30 \mathrm{~m}$ and $60 \mathrm{~m}$, (c) $60 \mathrm{~m}$ and $90 \mathrm{~m}$, and (d) $90 \mathrm{~m}$ and $141 \mathrm{~m}$. The dashed line shows equal PGAs for stations at two different depths.

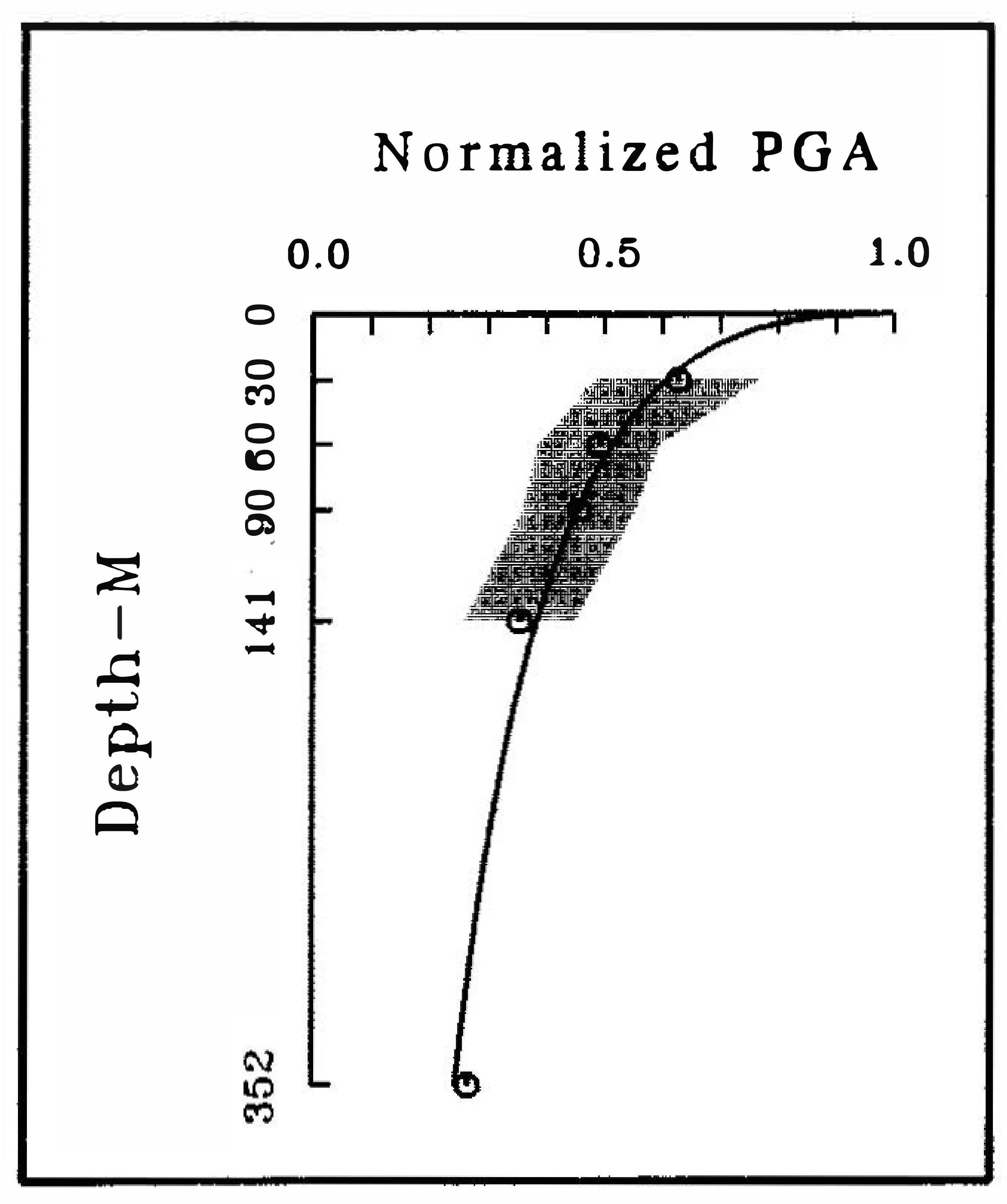

Fig. 9. Variations of the normalized PGA with respect to depth. The shaded area represents \pm 1 standard deviation around the average. 
The comparison of the amplitude spectrum at different depths shows the variations in amplitude at different frequencies. Ten-second records containing the shear wave were used to calculate the Fourier amplitude spectrum. The spectral ratio between different depths was calculated. Figure 10a shows an example of the spectral ratio between the record at ground surface and that at the $90-\mathrm{m}$ depth. The thickness of the Songshan Formation is about 110 meters. Hence, this spectral ratio can be seen as the frequency response of the Songshan Formation. Figure 10a shows the fundamental frequency is at about $1 \mathrm{~Hz}$, and the amplitude in this frequency can enlarge about $4 \sim 8$ times as the $S$-wave propagates from 90 meters in depth to ground surface. The fundamental frequency can also show the velocity within a two-station pair. In Figure 10b, the fundamental frequency of the spectral ratio between the amplitude spectrum at ground surface and that at the 30-meter depth is about $2 \mathrm{~Hz}$. Back calculated, the shear wave velocity from $\mathrm{V}_{s}=f .4 H$ is about $240 \mathrm{~m} / \mathrm{sec}$. This is not very different from the result calculated from the travel time analysis of $V_{s}=200 \pm 40 \mathrm{~m} / \mathrm{sec}$ (Table $3)$.
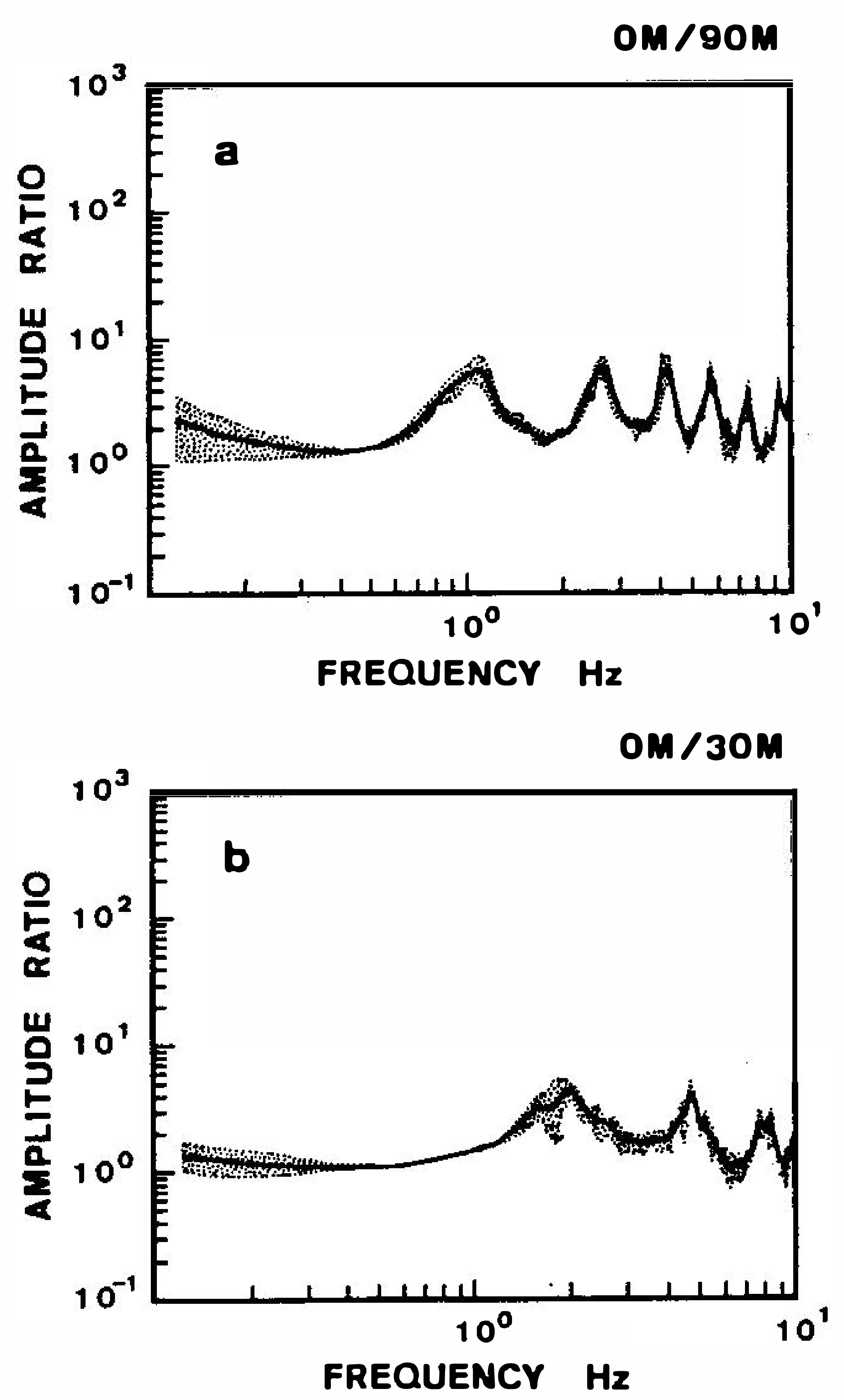

Fig. 10. Average spectra ratios between the S-wave spectrum at surface and that at (a) $90 \mathrm{~m}$, and (b) $30 \mathrm{~m}$. The shaded areas represent \pm 1 standard deviation of the average.

\section{CONCLUSIONS}

The installation of a downhole array is very useful for studying soil amplification effects. It can also give direct and reliable information for the seismic resistant design of engineering structures. For the Taipei Basin which has a dense population and a great many high-rise buildings on a soft soil layer, this instrumentation is very helpful.

Based on the travel times of the seismic waves observed at the Wuku downhole array, the average velocities at different depth layers can be calculated. The results are shown in 
Table 3. These average velocities can also be checked from the spectral ratios at different station pairs.

The comparison of the PGA at different depths shows that the amplification effect is very small when the seismic wave is propagated from a 141 -meter depth to one of 60 meters. The major amplification exists in the top 60 meters of the soft soil layer. This amplification effect is still in the range of the linear amplification for this weak motion data set. The equation shows the variation of the PGA with respect to depth in the Wuku area is obtained by using a linear regression analysis. The amplification effect of the Songshan Formation can be seen from the spectral ratio between the spectrum at ground surface and that at the 90 -meter depth. The fundamental frequency is about $1 \mathrm{~Hz}$, and the amplitude can be enlarged about $4 \sim 8$ times at this frequency.

With all the observations just beginning and the downhole array expanding to different sites, hopefully, the characteristics of the ground motions of the Taipei Basin during an earthquake may still be better understood. Accordingly, the seismic resistant design code of the Taipei area can be improved. This, in turn, will help mitigate the possible damage in any future earthquakes.

\section{Acknowledgments}

This work has been supported by the Central Geological Survey, Ministry of Economic Affairs under grants 81EC2A380005 and 82EC2A380005. Comments and suggestions by two anonymous reviewers are greatly appreciated. The authors would like to express special thanks to the technical staff of the Institute of Earth Sciences, Academia Sinica who are in charge of the installation and maintenance of the downhole array. The assistance of Mr. Liang-Fang Liu and Miss Hui-Yi Lee in the processing of the data is also greatly appreciated.

\section{REFERENCES}

Beresnev, I. A., K. L. Wen, and Y. T. Yeh, 1995a: Seismological evidence for nonlinearelastic ground behavior during large earthquakes. Soil Dyn. Earthq. Eng., 14, 2, 103-114.

Beresnev, I. A., K. L. Wen, and Y. T. Yeh, 1995b: Nonlinear soil amplification: its corroboration in Taiwan. Bull. Seism. Soc. Am., 85, 2, 496-515.

Çelebi, M., J. Prince, C. Dietel, M. Onate, and G. Chavez, 1987: The culprit in Mexico City-amplification of motions. Earthquake Spectra, 3, 315-328.

Chin, B.-H., and K. Aki., 1991: Simultaneous study of the source, path, and site effects on strong ground motion during the 1989 Loma Prieta earthquake: a preliminary result on pervasive nonlinear site effects. Bull. Seism. Soc. Am., 81, 1859-1884.

Fong, C. C., T. L. Shaw, C. C. Liu, and Y. B. Tsai, 1976: Geophysical Survey in Taipei City. Institute of Physics, Academia Sinica, Open-file Report. 152PP.

Gutenberg, B., 1957: Effects of ground on earthquake motion. Bull. Seism. Soc. Am., 47, 221-250.

Hudson, D. E., 1972: Local distribution of strang earthquake ground motions. Bull. Seism. Soc. Am., 62, 1765-1786. 
Kawase, H., and K. Aki, 1989: A study on the response of a soft basin for incident S, P, and Rayleigh waves with special reference to the long duration observed in Mexico City. Bull. Seism. Soc. Am., 79, 1361-1382.

Lin, C. M., 1994: Geophysics study in Wuku-Panchiao area of western Taipei basin. M.S. Thesis, National Central University, 106pp.

Lin, Y. I., C. Yang, M. C. Chang, and M. S. Chun, 1980: Shear wave velocity measurement results of the top soil (Songshan Formation) in Taipei basin and its preliminary study at the structural resistant design. Report of Dept. of Physics, National Taiwan Educational Univ. 72pp.

Liu, C. C., W. H. Liu, W. H. H. Lee, H. C. Cheng, Y. Y. Lee, and C. F. Wu, 1993: Application of building arrays instrumentation, Abstract of the Symposium on Taiwan Strong Motion Instrumentation Program, 46-50.

Peng, H.-Y., and K.-L. Wen, 1993: Downhole instrument orientations and near surface Q analysis from the SMART2 array data. TAO, 4, 367-380.

Tsai, C. C., Y. T. Yeh, K. L. Wen, S. N. Cheng, and M. H. Kao, 1986: The Hualien earthquake of May 20, 1986 : Strong ground motion data and response spectra. Bull. Inst. Earth Sci., Academia Sinica, 6, 29-64.

Tsai, I. C., 1988: Strong ground motion characteristics of Taipei basin in November 15, 1986 earthquake and its impact on structural design, Proc. CCNAA-AIT Joint Seminar on Research and Application for Multiple Hazards Mitigation, 195-208.

Vidale, J. E., and D. V. Helmberger, 1988: Elastic finite difference modeling of the 1971 San Fernando, California, earthquake. Bull. Seism. Soc. Am., 78, 122-141.

Wang, C. Y., and K. P. Chen, 1993: Local site effects of Lanyang plain, Abstract of the Symposium on Taiwan Strong Motion Instrumentation Program, 74-80.

Wang, C. Y., and W. F. Chuan, 1992: A preliminary study of site effect on Lanyang plain, Proc. of the Fourth Taiwan Symposium on Geophysics, 77-92.

Wang, C. Y., W. C. Hsiao, and C. T. Sun, 1994: Reflection seismic stratigraphy in the Taipei basin (I) - Northwestern Taipei. J. Geol. Soc. China, 37, 1, 69-95.

Wen, K. L., 1994: Non-linear soil response in ground motions. Earthq. Eng. Struct. Dyn., 23, 599-608.

Wen, K. L., and Y. T. Yeh, 1992: Analysis of peak ground motions observed by two dense arrays. J. Geol. Soc. China, 35, 2, 115-134.

Wen, K. L., Y. T. Yeh, and W. G. Huang, 1992: Effects of alluvial basin on strong ground motions. Bull. Seism. Soc. Am., 82, 2, 1124-1133.

Wen, K. L., I. A. Beresnev, and Y. T. Yeh, 1993: Check on nonlinear site response in strong ground motions by using the spectral ratio method. Proc. of the Third ROC and Japan Joint Seminar on Natural Hazards Mitigation, 89-101, National Cheng-Kung Univ., Tainan, Taiwan.

Wen, K. L., I. A. Beresnev, and Y. T. Yeh, 1994: Nonlinear soil amplification inferred from downhole strong seismic motion data. Geophys. Res. Lett., 21, 24, 2625-2628. 
Wen, K. L., I. A. Beresnev, and Y. T. Yeh, 1995: Investigation of nonlinear site amplification at two downhole strong ground motion arrays in Taiwan. Earthq. Eng. Struct. Dyn., 24, 3, 313-324.

Yamazaki, F., L. Lu, and T. Katayama, 1992: Orientation error estimation of buried seismographs in array observation. Earthq. Eng. Struct. Dyn., 21, 679-694.

Yeh, Y. H., C. H. Chen, and T. L. Teng, 1988: Study on focusing of seismic wave energy in Taipei basin. Proc. of the CCNAA-AIT Joint Seminar on Research and Application for Multiple Hazards Mitigation, 1, 107-120. 